\title{
Karakteristik Sosial Ekonomi Dan Tipologi Migrasi Migran Asal Jawa Di Kuta Selatan-Bali
}

\author{
I Made Sarmita ${ }^{1 *}$ Alexander Hamonangan Simamora ${ }^{2}$
}

1 Jurusan Pendidikan Geografi, FHIS, Universitas Pendidikan Ganesha, Singaraja ${ }^{2}$ Jurusan Teknologi Pendidikan, FIP, Universitas Pendidikan Ganesha, Singaraja

\section{A R T I C L E I N F O}

Article history: Received 31 Oktober 2018

Accepted 30 November 2018

Available online 31

Desember 2018

\section{Kata Kunci:}

Tipologi Migrasi;

Karakteristik Sosial-

Ekonomi; Migran Asal Jawa

Keywords:

Migration Typology; SocioEconomic Characteristics; Javanese Migrants

\begin{abstract}
A B S T R A K
Tujuan dan target khusus dilakukannya penelitian ini adalah untuk mengungkap karakteristik sosial ekonomi migran asal Jawa, serta berusaha mengembangkan konsep migrasi melalui analisis tipologi migrasi. Untuk mencapai tujuan tersebut, penelitian dilakukan dengan menggunakan metode survei. Analisis data menggunakan teknik statistik deskriptif. Hasil penelitian menunjukkan bahwa karakteristik sosial ekonomi migran asal Jawa di Kuta Selatan diantaranya adalah didominasi migran yang berumur sangat produktif dalam bekerja (20-34 tahun), berjenis kelamin laki-laki, berstatus kawin, berpendidikan SMA, memiliki skill yang terkategori setengah terampil, dan memiliki penghasilan yang terkategori tinggi dan sangat rendah. Tipe migrasi bisa dibedakan menjadi empat, yaitu permanen, potensial permanen, sirkuler, dan potensial sirkuler. Untuk migran asal Jawa di Kuta Selatan hampir setengahnya terkategori migran potensial sirkuler. Pembagian tipe migrasi tersebut sangat bermanfaat dalam analisis migrasi. Hal itu ditunjukkan kenyataan bahwa ada kecenderungan karakteristik migran yang termasuk dalam
\end{abstract} kategori permanen dan potensial permanen mempunyai pola yang sama dilihat dari umur, jenis kelamin, pendidikan, skill, kondisi ekonomi maupun status kawin. Begitu pula migran kategori sirkuler dan potensial sirkuler memiliki kecenderungan yang sama dalam semua karakteristik.

\begin{abstract}
A B S T R A C T
The specific objective and target of this research is to reveal the socio-economic characteristics of migrants from Java, and try to develop the concept of migration through a typology of migration analysis. To achieve these objectives, research is carried out using survey methods. Data analysis using descriptive statistical techniques. The results showed that the socio-economic characteristics of migrants from Java in South Kuta were predominantly migrants of very productive age in employment (20-34 years), male sex, married status, high school education, possessing half-skilled skills, and have high and very low categorized income. The type of migration can be divided into four, namely permanent, permanent potential, circular, and circular potential. For migrants from Java in South Kuta almost half are categorized as potentially circular migrants. This type of migration is very useful in migration analysis. It was shown by the fact that there was a tendency for migrant characteristics included in the permanent and potential permanent category to have the same pattern seen from age, sex, education, skills, economic conditions and marital status. Likewise migratory circular and circular potential categories have the same tendency in all characteristics.
\end{abstract}




\section{Pendahuluan}

Dalam mendefinisikan migrasi, Zelinsky (1971) membedakan antara migrasi dan sirkulasi. Migrasi didefinisikan sebagai "any permanent or semipermanent change of residence", sedangkan sirkulasi adalah "a great variety of movements usually short-term, repetitive or cyclical in nature, but all having in common the lack of any declared intention to of a permanent or long-lasting change in residence". Begitu pula Rusli (2012) dan Mantra (2000) menyatakan migrasi merupakan dimensi gerak penduduk yang melintas batas wilayah asal menuju wilayah lain dengan ada niatan menetap di daerah tujuan, sedangkan dimensi gerak penduduk nonpermanen terdiri dari sirkulasi dan komutasi, yakni gerak penduduk dari suatu wilayah menuju wilayah lain dengan tidak ada niatan menetap di daerah tujuan. Dari beberapa definisi ini dapat diambil kesimpulan bahwa intention to shift residence merupakan salah satu faktor yang penting dalam pembedaan antara migrasi yang sifatnya permanen dan yang sifatnya sementara.

Tetapi dengan membedakan migrasi menjadi sekedar permanen, sirkuler dan commuting/penglaju, konsep migrasi sebagai sebuah proses menjadi terabaikan. Dalam proses, selain kategori yang sifatnya sudah definitif seperti permanen atau sirkuler, kemungkinan ada kategori lain yang berada di antara kedua hal tersebut. Hal ini akan berlaku dalam kasus ketika kepastian pindah belum ada. Ada kemungkinan bahwa pada satu peringkat tertentu seorang migran sirkuler akan berubah menjadi migran permanen, dan sebaliknya migran permanen bisa berubah menjadi migran sirkuler oleh karena sesuatu hal. Dengan demikian, ada satu fase di mana migran masih belum dapat diklasifikasikan sebagai migran sirkuler atau migran permanen.

Keadaan yang demikian tentunya tidak terlepas dari kondisi sosial ekonomi migran terutama dalam prosesnya mengadaptasi kondisi di daerah tujuan migrasi. Seseorang yang merasa bahwa keadaannya di daerah tujuan cukup "mapan" secara sosial maupun ekonomi, cenderung untuk menjadi migran permanen. Sebaliknya dengan kondisi yang "pas-pasan" apalagi serba kekurangan, sepertinya sangat sulit bagi si migran untuk menetap di daerah tujuan.

Adaptasi erat kaitannya dengan lamanya migran tinggal di daerah tujuan. Asumsinya adalah bahwa semakin lama migran berada di daerah tujuan, pemahaman terhadap daerah tujuan tersebut juga semakin mendalam, sehingga keputusan yang diambil baik untuk melakukan migrasi sirkuler maupun permanen sudah mempunyai dasar yang kuat.

Kekakuan dalam memahami tipologi migrasi yang terjadi selama ini sekiranya perlu diurai dan dikembangkan kembali, sehingga konsep migrasi kedepannya selalu dipandang sebagai sebuah proses. Kaitannya dengan hal tersebut, pengembangan konsep migrasi dipandang lebih tepat digunakan dalam penelitian mikro yang dilaksanakan di daerah tujuan daripada penelitian yang dilakukan di daerah asal.

Beranjak dari kemendesakan dalam pengembangan konsep migrasi melalui analisis tipologi migrasi, kasus migran asal Jawa yang saat ini berada di Kecamatan Kuta Selatan Bali bisa menjadi pilihan yang ideal. Pemahaman mengenai tipologi migran di wilayah ini menjadi begitu penting seiring semakin derasnya kaum pendatang yang memasuki wilayah Kuta Selatan. Tanpa pemahaman tipologi migrasi dari para migran, penyusunan kebijakan-kebijakan terkait akan menjadi rancu dan tidak terarah.

Pertumbuhan penduduk di Kuta Selatan jauh melebihi batas minimal ( $>2,5 \%$ per tahun) yakni sebesar 7.65\% (Perhitungan secara eksponensial dari data Kuta Selatan Dalam Angka Tahun 2011 dan 2016), merefleksikan bahwa perpindahan penduduk (migrasi masuk) sangat memberi kontribusi terhadap angka pertumbuhan penduduk tersebut (Romdiati, 2007). Dikatakan demikian, karena kecenderungan jumlah migrasi masuk selalu lebih besar daripada migrasi keluarnya dalam beberapa kurun waktu terakhir yang dapat dilihat pada tabel 1 berikut. 
Tabel 1 Jumlah Penduduk, Migrasi Masuk, Migrasi Keluar, dan Migrasi Netto dii Kecamatan Kuta Selatan Tahun 2010-2015

\begin{tabular}{|c|c|c|c|c|c|}
\hline No & Tahun & $\begin{array}{c}\text { Jumlah } \\
\text { Penduduk }\end{array}$ & Migrasi Masuk & Migrasi Keluar & Migrasi Netto \\
\hline 1 & 2010 & 71716 & 1049 & 690 & 359 \\
\hline 2 & 2011 & 73134 & 1202 & 631 & 571 \\
\hline 3 & 2012 & 83527 & 9717 & 1029 & 8688 \\
\hline 4 & 2013 & 93256 & 9846 & 901 & 8945 \\
\hline 5 & 2014 & 105059 & 7221 & 1926 & 5295 \\
\hline 6 & 2015 & 105116 & 7220 & 1924 & 5296 \\
\hline
\end{tabular}

Sumber : Kuta Selatan Dalam Angka 2011-2016

Masalah kependudukan, khususnya penduduk migran di daerah Kuta Selatan kini terasa kian mengemuka. Ibarat peribahasa "ada gula ada semut", gemerlap dunia pariwisata tidak saja menarik minat para wisatawan untuk berkunjung, tetapi juga merangsang kehadiran kaum migran untuk mengais rezeki di daerah ini. Dari sekian migran yang ada, diyakini diantaranya terdapat migran yang berasal dari Jawa. Dikatakan demikian karena dari hasil observasi awal sangat mudah menjumpai migran-migran asal Jawa di setiap sudut wilayah di Kuta Selatan, baik yang bekerja di sektor formal dan terutama pada sektor informal. Selain itu, disadari bahwa proses migrasi migran asal Jawa ke pulau Bali umumnya dan Kuta Selatan khususnya mempunyai akar sejarah yang panjang dan proses tersebut berkembang karena jarak antara dua wilayah yang dekat serta hubungan transportasi yang lancar. Dengan kedatangan migran ini mengakibatkan kondisi penduduk di Kuta Selatan semakin heterogen yang bisa menjadi pemicu dari munculnya permasalahan-permasalahan sosial. Apabila persoalan tentang migran utamanya terkait dengan karakteristik sosial ekonomi tidak dikenali dengan pasti, maka dikhawatirkan akan menimbulkan berbagai permasalahan yang lebih kompleks dan bisa mempengaruhi citra Bali secara keseluruhan. Bersamaan dengan subjek yang dikaji itu pula akan dapat dikembangkan konsep migrasi melalui analisis tipologi migrasi dari migran asal Jawa di Kuta Selatan.

\section{Metode}

Metode penelitian yang digunakan dalam penelitian ini adalah dengan rancangan survei deskriptif. Survei adalah metode pengumpulan informasi dari sejumlah sampel sebagai responden yang difasilitasi dengan kuesioner (Effendi dan Tukiran, 2012). Pengambilan sampel wilayah/lokasi ditentukan dengan teknik purposive sampling dengan memilih satu wilayah/desa di Kuta Selatan yang penduduk migrannya paling banyak. Dengan teknik itu terpilih Desa Jimbaran sebagai sampel wilayah. Selanjutnya sampel individu ditentukan dengan teknik snowball Analisis data dilakukan dengan teknik deskriptif dan tabel silang/ crosstab.

\section{Hasil dan pembahasan}

1. Karakteristik Sosial Ekonomi Migran

Migran sebagai bagian dari populasi manusia memiliki karakteristik sosial ekonomi yang spesifik, berbeda diantara migran satu dengan migran lainnya. Dalam penelitian ini, karakteristik sosial ekonomi migran dibatasi pada beberapa variabel seperti umur, jenis kelamin, status perkawinan, pendidikan, skill yang dimiliki, dan penghasilan bersih yang diterima migran sebagai hasil jerih payahnya bekerja di Kuta Selatan. Karakteristik tersebut bisa jadi akan berbeda dan sama sekali kontras dengan karakteristik migran di wilayah lainnya. Oleh karenanya, hal ini bersifat relatif, namun tetap berguna sebagai gambaran awal mengenai ciriciri spesifik sebagian migran asal Jawa yang saat ini menghuni wilayah Kuta Selatan. Gambaran karakteristik migran ini juga dijadikan acuan dalam membahas tipologi migrasinya yang akan dipaparkan pada bagian selanjutnya. Berdasarkan hasil penelitian, diperoleh data seperti yang ditunjukkan tabel 2 berikut

Tabel 2. Karakteristik Sosial Ekonomi Migran Asal Jawa di Kuta Selatan 


\begin{tabular}{|c|l|l|}
\hline No & $\begin{array}{c}\text { Karakteristik } \\
\text { Sosial Ekonomi }\end{array}$ & \multicolumn{1}{c|}{ Hasil Penelitian } \\
\hline 1 & Umur & Didominasi umur Produktif (20-34 tahun) (59\%) \\
\hline 2 & Jenis Kelamin & Didominasi migran laki-laki (71\%) \\
\hline 3 & Status Kawin & Didominasi migran yang telah kawin (65\%) \\
\hline 4 & Pendidikan & Didominasi Tingkat SMA Keatas (65\%) \\
\hline 5 & Skill & Didominasi pekerja setengah terampil (75\%) \\
\hline 6 & Penghasilan Bersih & $\begin{array}{l}\text { Didominasi Yang Berpenghasilan Tinggi (45\%) dan } \\
\text { Sangat Rendah (30\%) }\end{array}$ \\
\hline
\end{tabular}

Salah satu hukum migrasi Revenstein menyatakan bahwa motif utama penduduk melakukan migrasi adalah motif ekonomi (Lee, 2000; Rusli, 2012). Mereka yang bermigrasi karena motif ekonomi pada umumnya adalah tenaga-tenaga kerja produktif. Dalam penelitian ini dapat dikatakan bahwa dominasi migran asal Jawa berumur produktif di wilayah Kuta Selatan adalah untuk bekerja yang di daerah asalnya di Jawa tidak tersedia dan persaingan yang ketat untuk memperoleh suatu pekerjaan. Mereka pada akhirnya memilih Kuta Selatan sebagai tempat mencari nafkah untuk menyambung hidupnya. Selain itu, dominasi migran berumur produktif sangat memungkinkan untuk terus melakukan migrasi sirkuler, dalam arti sementara tinggal di Kuta Selatan dan secara periodik pulang ke daerah asal di Jawa. Kelompok umur tersebut cukup mendukung terjadinya sirkulasi, karena kondisi pada umur tersebut masih prima atau tenaga fisik untuk melakukan migrasi sirkuler masih kuat.

Dalam hukum migrasi Revenstein (Lee, 2000) yang lain, dinyatakan bahwa perempuan melakukan migrasi dengan jarak yang lebih dekat dibandingkan dengan laki-laki. Dalam kasus penelitian ini, hukum tersebut belum sepenuhnya terbukti, namun sudah menuju ke arah itu dibuktikan dari begitu dominasinya migran laki-laki di Kuta Selatan. Jarak antara Jawa dengan Kuta Selatan adalah relatif, diukur dengan satuan kilometer paling dekat jaraknya tetap mencapai ratusan kilometer, sementara jika diukur dalam satuan waktu, paling cepat dapat ditempuh dalam waktu 5-6 jam dan paling lama adalah lebih dari 1 hari (via darat). Dengan jarak yang ada tersebut lebih memungkinkan laki-laki yang melakukan migrasi dibandingkan perempuan karena dalam perjalanan menuju ke Kuta Selatan dari Jawa cukup banyak menguras energi.

Dilihat dari status kawin, karakteristik migran asal Jawa didominasi oleh migran yang telah menikah. Migran yang telah menikah tentu memiliki beban tanggungan yang lebih berat. Ketika mereka dihadapkan dengan kesulitan di daerah asal dalam mencari pekerjaan, mereka pada akhirnya akan memilih daerah manapun termasuk Kuta Selatan sebagai daerah tujuan yang dipandang mampu menafkahi mereka dan keluarganya. Seperti yang dikatakan oleh Kasto (2002), pelaku mobilitas akan mencari pekerjaan di wilayah mana pun selama di wilayah tersebut dia mendapatkan upah yang tinggi. Apabila mereka tidak bermigrasi dalam rangka untuk bekerja, para migran utamanya yang telah menikah akan dihadapkan pada situasi yang serba sulit dari sisi ekonomi sehingga rentan terjebak dalam kemiskinan.

Tingkat pendidikan migran didominasi tamatan SMA ke atas. Sesuai dengan status mereka yang kebanyakan berusia produktif, di zaman yang serba mudah dalam mengakses pendidikan, sangat wajar jika migran berusia produktif telah sempat mengenyam pendidikan baik di daerah asalnya maupun di daerah lainnya. Tingkat pendidikan menengah ke atas tersebut sangat mendukung mereka dalam memperoleh pekerjaan yang layak di Kuta Selatan. Banyak dari mereka telah terserap dalam sektor pariwisata seperti menjadi karyawan swasta/hotel. Dengan tingkat pendidikan tersebut, migran memiliki wawasan yang lebih luas, cukup bermanfaat dan menjadi bekal dalam menjalani kehidupan.

Sejalan dengan pendidikan yang telah ditempuh, skill yang dimiliki oleh $3 / 4$ migran terkategori setengah terampil dalam klasifikasi ketenagakerjaan. Setengah terampil ini mencakup bidang tata usaha, usaha penjualan, dan usaha jasa.

Penghasilan migran sebagai hasil jerih payahnya bekerja di daerah Kuta Selatan secara garis besarnya didominasi dan terkelompok dalam dua kelas, yaitu berpenghasilan tinggi dan 
berpenghasilan sangat rendaah. Penghasilan terkategori tinggi diperoleh oleh migran yang profesinya sebagai wiraswasta seperti menjalankan bisnis mebel, membuka usaha spa, dan bisnis tanaman hias. Pada sisi lainnya, penghasilan rendah yang diperoleh migran adalah hasil mereka bekerja dalam membuka usaha warnet. Usaha ini sebenarnya cukup menjanjikan, tetapi antusias masyarakat dalam memanfaatkan jasa warnet semakin berkurang seiring dengan semakin majunya teknologi wi-fi dan sejenisnya.

Hasil analisis karakteristik sosial ekonomi migran diatas secara keseluruhan menunjukkan bahwa, migran asal Jawa di Kuta Selatan memiliki karakteristik yang begitu bervariasi. Sekali lagi hasil dan analisis ini tidak berlaku umum, namun dapat memberikan informasi awal utamanya bagi pemerintah dari tingkat desa hingga kabupaten dan provinsi untuk dijadikan cerminan dan bahan refleksi dalam merumuskan kebijakan kependudukan khususnya terkait dengan para pendatang/migran.

\section{Tipologi Migrasi}

Tipologi migrasi adalah jenis atau ragam tipe migrasi yang pengklasifikasiannya didasarkan atas beberapa indikator. Sejauh ini, beberapa ahli mobilitas mengklasifikasikan migrasi menjadi dua, yaitu permanen dan sirkuler dengan variabel niat migrasi selanjutnya menjadi kunci penentu untuk menggolongkan seseorang menjadi migran permanen atau sirkuler. Apabila seseorang memiliki niat menetap di daerah tujuan, digolongkan migran permanen, dan apabila seseorang tidak memiliki niat menetap digolongkan migran sirkuler. Para ahli kebanyakan melihat migrasi sebagai sebuah hasil, padahal kenyataannya migrasi adalah sebuah proses yang dalam perjalanannya bisa akan berubah, tidak hanya sekedar permanen maupun sirkuler (Sukamdi, 1991). Adalah niat seseorang, tidak dapat diukur begitu saja, karena niat seseorang bisa akan berubah-ubah. Dengan memasukkan lama tinggal seorang migran di daerah tujuan, niatnya akan dapat dipastikan atau setidaknya mendekati kebenaran. Semakin lama seorang migran didaerah tujuan, semakin mampu ia mengadaptasi daerah tujuan, semakin dapat dipastikan niat migrasi selanjutnya, begitu pula sebaliknya. Berikut dalam tabel 3 disajikan mengenai karakteristik mobilitas dari migran asal Jawa di Kuta Selatan.

Tabel 3. Karakteristik Mobilitas Migran Asal Jawa di Kuta Selatan

\begin{tabular}{|c|l|l|}
\hline No & \multicolumn{1}{|c|}{$\begin{array}{c}\text { Karakteristik } \\
\text { Mobilitas }\end{array}$} & \multicolumn{1}{c|}{ Hasil Penelitian } \\
\hline 1 & $\begin{array}{l}\text { Niat Migrasi } \\
\text { Selanjutnya }\end{array}$ & $\begin{array}{l}\text { Didominasi migran dengan niat tidak menetap di daerah } \\
\text { tujuan (69\%) }\end{array}$ \\
\hline 2 & $\begin{array}{l}\text { Lama Tinggal di } \\
\text { Daerah Tujuan }\end{array}$ & $\begin{array}{l}\text { Persentase hampir berimbang, lama tinggal < 5 tahun } \\
\text { sedikit lebih banyak (52\%) dibandingkan lama tinggal > } \\
5 \text { tahun (48\%) }\end{array}$ \\
\hline
\end{tabular}

Berdasarkan tabel 3 di atas, mengikuti apa yang sudah diklasifikasikan oleh para ahli mobilitas, dapat dikatakan bahwa sebagian besar migran asal Jawa di Kuta Selatan adalah migran sirkuler. Padahal kalau dilihat dalam tabel, ada variabel lama tinggal yang persentasenya hampir berimbang yang bisa menjadi faktor penentu niat migrasi selanjutnya. Mereka yang menyatakan niatnya baik untuk tidak menetap maupun menetap namun lama tinggalnya masih di bawah 5 tahun di Kuta Selatan, adalah jawaban yang belum pasti atau meragukan. Mereka diasumsikan belum mampu mengadaptasi kondisi daerah tujuan sehingga niatnya bisa jadi akan berubah. Sebaliknya migran yang menyatakan niatnya baik untuk tidak menetap maupun menetap dengan lama tinggal sudah lebih dari 5 tahun di Kuta Selatan, jawabannya lebih meyakinkan karena mereka diasumsikan sudah mampu mengadaptasi, mengenal daerah tujuan dengan baik.

Batasan waktu 5 tahun digunakan didasarkan atas standar perbedaan yang digunakan dalam literatur migrasi, terutama merujuk pada konsep recent migrant yang menggunakan batasan waktu 5 tahun sebagai cutting point. Batasan ini sesuai juga dengan batasan yang digunakan oleh Departemen Transmigrasi, bahwa transmigran dianggap sudah memenuhi 
kriteria tertentu untuk dapat diserahkan kepada Pemda setempat setelah 5 tahun berada di lokasi transmigrasi (Sukamdi, 1991).

Berdasarkan atas 2 variabel yang ada tersebut, maka dapat disusun beberapa tipe migrasi, diantaranya: migran permanen (niat menetap, lama tinggal $>5$ tahun), migran sirkuler (niat tidak menetap, lama tinggal $>5$ tahun), migran potensial permanen (niat menetap, lama tinggal $<5$ tahun), dan migran potensial sirkuler (niat tidak menetap, lama tinggal $<5$ tahun). Hasil penerapan empirik untuk migran asal Jawa di Kuta Selatan diperoleh hasil sesuai tabel 4 berikut.

Tabel 4. Distribusi Migran Menurut Niat Menetap, Lama Tinggal, dan Tipologi Migrasi

\begin{tabular}{|l|c|c|}
\hline \multicolumn{1}{|c|}{ Keinginan Menetap } & Frekuensi & Persentase \\
\hline Ya & 31 & 31 \\
\hline Tidak & 69 & 69 \\
\hline Lama Tinggal & & 52 \\
\hline Kurang Dari 5 Tahun & 52 & 48 \\
\hline Lebih Dari 5 Tahun & 48 & \\
\hline Tipologi Migrasi & & 26 \\
\hline Permanen & 26 & 5 \\
\hline Potensial Permanen & 5 & 47 \\
\hline Potensial Sirkuler & 47 & 22 \\
\hline Sirkuler & 22 & \\
\hline
\end{tabular}

Berdasarkan tabel 4 di atas, hampir setengah (47\%) dari total responden sangat potensial menjadi migran sirkuler. Hal ini didasarkan atas jawaban yang diberikan yakni mereka tidak berniat menetap di Kuta Selatan, dan di sisi lain mereka baru tinggal di Kuta Selatan kurang dari 5 tahun. Jawaban untuk tidak menetap di Kuta Selatan juga merefleksikan bahwa migran mempunyai keterikatan yang masih kuat dengan daerah asal yang salah satu penyebabnya adalah lama tinggal di Kuta Selatan yang belum memadai sehingga belum bisa menurunkan keterikatan tersebut. Seiring berjalannya waktu, mereka akan mampu mengadaptasi kondisi daerah Kuta Selatan sehingga berpengaruh terhadap niat migrasi selanjutnya. Dengan demikian sangat memungkinkan tipe migrasinya juga akan berubah.

Pada sisi lainnya, terlihat lebih dari $1 / 4$ responden yang sudah mantap keinginannya untuk menjadi migran permanen. Hal ini didasari jawaban mereka yang berniat menetap di Kuta Selatan dan lama tinggalnya yang sudah lebih dari 5 tahun. Dengan bertempat tinggal yang cukup lama tersebut, mereka sudah mampu mengadaptasi kondisi daerah tujuan sehingga memutuskan untuk menetap di Kuta Selatan. Hal ini didukung oleh hasil penelitian sebelumnya dari Sarmita dan Suyasa (2017), yang menunjukkan bahwa migran yang sudah lama tinggal di Kuta Selatan sudah memiliki tempat tinggal yang permanen dan layak sehingga menjadikan niatnya untuk menetap semakin tinggi.

Secara keseluruhan, dari 100 orang responden yang dapat digolongkan telah memiliki keinginan yang mantap baik untuk menetap maupun tidak menetap adalah sejumlah 48\%, terdiri dari $26 \%$ permanen, dan $22 \%$ sirkuler. Responden lainnya termasuk kedalam apa yang disebut dengan potensial permanen (5\%) dan potensial sirkuler (47\%). Artinya dengan hanya menggunakan "keinginan untuk menetap" sebagai satu-satunya indikator untuk membuat tipologi migrasi, maka sebagian besar migran (52\%) yang berada pada posisi "antara" migrasi permanen dan sirkuler menjadi terabaikan.

Salah satu cara untuk melihat apakah dengan menggunakan tipologi semacam ini bermanfaat atau tidak, adalah dengan mengetahui karakteristik migran pada masing-masing tipe migrasi. Asumsinya adalah jika migran yang berada dalam kategori migran potensial permanen maupun potensial sirkuler mempunyai karakteristik yang spesifik sehingga dapat dilihat perbedaannya dengan kategori yang lain, maka penggunaan tipologi ini dapat dijustifikasi. Hal ini didasarkan pada pemikiran bahwa kemampuan migran untuk mengadaptasi kondisi di daerah tujuan sangat tergantung pada karakteristik individu (Peek dan Antolinez, 
1977). Disamping itu, pendapatan migran di daerah tujuan dapat dijelaskan berdasarkan karakteristik individu (Oberai dan Billsborow, 1984; Speare and Harris,1986). Diharapkan dengan karakteristik yang berbeda akan dapat dijelaskan kondisi sosial ekonomi masing-masing tipe migrasi. Secara keseluruhan, karakteristik sosial ekonomi masing-masing tipe migrasi yang ada disajikan pada tabel 5 berikut.

Tabel 5 Karakteristik Sosial Ekonomi Migran Menurut Tipe Migrasi

\begin{tabular}{|c|c|c|c|c|}
\hline \multirow[b]{2}{*}{ Karakteristik Sosial Ekonomi } & \multicolumn{4}{|c|}{ Tipologi Migrasi } \\
\hline & Permanen & $\begin{array}{l}\text { Potensial } \\
\text { Permanen }\end{array}$ & $\begin{array}{l}\text { Potensial } \\
\text { Sirkuler }\end{array}$ & Sirkuler \\
\hline \multicolumn{5}{|l|}{ Jenis Kelamin } \\
\hline Laki-Laki & 21 & 4 & 30 & 16 \\
\hline Perempuan & 5 & 1 & 17 & 6 \\
\hline \multicolumn{5}{|l|}{ Umur } \\
\hline$<20$ & 1 & 0 & 4 & 0 \\
\hline $20-<40$ & 5 & 1 & 40 & 20 \\
\hline $40-<60$ & 20 & 4 & 3 & 2 \\
\hline $60+$ & 0 & 0 & 0 & 0 \\
\hline \multicolumn{5}{|l|}{ Pendidikan } \\
\hline Tidak Tamat SD & 7 & 0 & 0 & 0 \\
\hline Tamat SD & 10 & 3 & 2 & 0 \\
\hline Tidak Tamat SMP & 3 & 1 & 2 & 0 \\
\hline Tamat SMP & 1 & 0 & 2 & 2 \\
\hline Tidak Tamat SMA & 0 & 0 & 1 & 1 \\
\hline Tamat SMA & 3 & 0 & 26 & 6 \\
\hline Tamat Diploma & 1 & 0 & 9 & 9 \\
\hline Tamat Sarjana & 1 & 1 & 5 & 4 \\
\hline \multicolumn{5}{|l|}{ Skill } \\
\hline Tidak Terampil & 8 & 2 & 1 & 1 \\
\hline Setengah Terampil & 16 & 3 & 41 & 15 \\
\hline Terampil & 2 & 0 & 5 & 6 \\
\hline \multicolumn{5}{|l|}{ Kondisi Ekonomi } \\
\hline Sangat Rendah & 20 & 4 & 5 & 1 \\
\hline Rendah & 1 & 1 & 0 & 0 \\
\hline Sedang & 0 & 0 & 10 & 6 \\
\hline Tinggi & 4 & 0 & 28 & 13 \\
\hline Sangat Tinggi & 1 & 0 & 4 & 2 \\
\hline \multicolumn{5}{|l|}{ Status Kawin } \\
\hline Kawin & 22 & 3 & 24 & 16 \\
\hline Belum Kawin & 4 & 1 & 21 & 5 \\
\hline Janda & 0 & 0 & 2 & 0 \\
\hline Duda & 0 & 1 & 0 & 1 \\
\hline
\end{tabular}

Secara keseluruhan, ada kecenderungan bahwa karakteristik migran yang termasuk dalam kategori permanen dan potensial permanen mempunyai pola yang sama baik dilihat dari jenis 
kelamin, umur, pendidikan, skill, kondisi ekonomi maupun status kawin. Migran permanen dan potensial permanen karakteristiknya didominasi oleh laki-laki, berumur 40 tahun ke atas, berpendidikan SD, skill setengah terampil mengarah ke tidak terampil, kondisi ekonomi sangat rendah, dan sebagian besar berstatus kawin.

Begitu pula migran kategori sirkuler dan potensial sirkuler memiliki kecenderungan yang sama dalam semua karakteristik. Migran sirkuler dan potensial sirkuler memiliki karakteristik didominasi laki-laki, berumur $20-<40$ tahun, berpendidikan SMA ke atas, skill setengah terampil mengarah ke terampil, kondisi ekonomi tinggi, berstatus kawin dan tidak sedikit pula yang belum kawin.

Dengan pembagian tipe migrasi ini, studi mengenai keadaan sosial ekonomi migran di daerah tujuan migrasi akan lebih lengkap dan bermanfaat dibandingkan apabila tipe migrasi hanya dibedakan menurut pembagian yang klasik. Maksudnya bahwa analisis migrasi selain didasarkan atas pembagian yang telah ada, yaitu permanen dan sirkuler, dapat juga didasarkan atas pengklasifikasian di atas, yaitu migran yang dianggap sudah menentukan sikap secara pasti, baik permanen maupun sirkuler di satu pihak, dan di lain pihak migran yang masih diragukan keputusannya untuk masuk ke dalam salah satu tipe migrasi, dalam hal ini adalah potensial permanen dan potensial sirkuler.

\section{Simpulan dan saran}

Karakteristik sosial ekonomi migran asal Jawa di Kuta Selatan dapat dilihat dari beberapa indikator Dari indikator umur terlihat bahwa migran asal Jawa didominasi migran dengan umur sangat produktif dalam bekerja yakni 20-34 tahun. Kemudian dilihat dari jenis kelamin, migran asal Jawa begitu didominasi oleh migran laki-laki. Berdasarkan status kawinnya, migran didominasi oleh migran yang telah kawin sehingga tanggungan terhadap keluarga menjadi besar. Berdasarkan pendidikan yang telah ditamatkan, migran didominasi oleh mereka yang telah menyelesaikan pendidikannya pada jenjang SMA. Dilihat dari skill yang dimiliki, sebagian besar migran terkategori memiliki skill setengah terampil. Berdasarkan penghasilan bersih yang diperoleh migran setelah bekerja di Kuta Selatan, didominasi oleh dua kelompok yakni migran yang berpenghasilan tinggi dan migran yang berpenghasilan sangat rendah.

Pengembangan konsep migrasi melalui analisis tipologi migrasi memberikan hasil bahwa tipe migrasi bisa dibedakan menjadi empat, yaitu permanen, potensial permanen, sirkuler, dan potensial sirkuler. Untuk migran asal Jawa di Kuta Selatan hampir setengahnya terkategori migran potensial sirkuler. Hasil penerapan secara empirik menunjukkan bahwa pembagian tersebut sangat bermanfaat dalam analisis migrasi. Hal itu ditunjukkan kenyataan bahwa ada kecenderungan karakteristik migran yang termasuk dalam kategori permanen dan potensial permanen mempunyai pola yang sama dilihat dari umur, jenis kelamin, pendidikan, skill, kondisi ekonomi maupun status kawin. Begitu pula migran kategori sirkuler dan potensial sirkuler memiliki kecenderungan yang sama dalam semua karakteristik.

\section{Daftar Rujukan}

Badan Pusat Statistik. 2011-2016. Kecamatan Kuta Selatan Dalam Angka. Badung: Bappeda Litbang dan BPS Kabupaten Badung Rusli S. 2012. Pengantar Ilmu Kependudukan, edisi Revisi. Jakarta: LP3ES

Effendi, Sofian dan Tukiran. 2012. Metode Penelitian Survei. Jakarta: LP3ES

Kasto. 2002. Mobilitas Penduduk Dan Dampaknya Terhadap Pembangunan Daerah (Dalam Buku Mobilitas Penduduk Indonesia Tinjauan Lintas Disiplin). Yogyakarta : PSKK UGM

Lee, Everett S. 2000. Teori Migrasi (Seri Terjemahan No 3). Yogyakarta: PPK UGM

Mantra, I.B. 2000. Demografi Umum. Yogyakarta: Pustaka Pelajar

Oberai,A.S dan Billsborrow,R.E. 1984. Theoretical Perspective On Migration (Dalam Billsborrow, et.al., Migration In Low Income Countries: Guidelines For Survey and Questionaire). London: Croom Helm

Peek,P dan Antolinez,P. 1977. Migration and The Urban Labor Market: The Case Of San Salvador. World Development, 5(4): 291-302 
Romdiati. 2007. Mobilitas Penduduk Temporer Di Permukiman Kumuh Kota Surabaya: Pengelolaan Dan Konteksnya Terhadap Penataan Lingkungan. Jakarta: LIPI

Sarmita, I. Made, and P. Wayan Artha Suyasa. Penyesuaian Diri Migran Sirkuler Asal Jawa Di Kecamatan Kuta Selatan-Bali. Proceeding SENARI 5 (2017): 80-87.

Speare, Alden, Jr and John Harris. 1986. Education, Earnings, and Migration In Indonesia. Economic Development and Cultural Change, 34 (2): 233-244

Sukamdi. 1991. Tipologi Migrasi: Suatu Alternatif Pengembangan Konsep. Populasi, 1 (2)

Zelinsky, W. 1971. The Hypothesis Of The Mobility Transition. Geographical Review, 61 (2) 